\title{
Population-based Childhood Immunization Education Intervention Program: Process and Impact Assessment
}

\author{
Article by Gbadebo O Ogungbade ${ }^{1,2}$, James Oloyede ${ }^{3}$, Oluwole Odutolu ${ }^{4}$, Larry Holmes, $\mathrm{Jr}^{5}$ \\ ${ }^{1}$ Ph.D, Global Health Services Initiatives, \\ ${ }^{2}$ Adeleke University, Faculty of Health Sciences, Nigeria \\ ${ }^{3}$ M.Sc., Department of Primary Health Care, Nigeria. \\ ${ }^{4} \mathrm{MD}$, Senior Health Specialist, Nigeria. \\ ${ }^{5}$ PH, Biological Science Department, University of Delaware \\ E-mail:debogungbade@gmail.com ${ }^{1}$,sanjames2006@gmail.com ${ }^{3}$, aodutolu@worldbank.org 4 , \\ drlholmesjr@gmail.com ${ }^{5}$
}

\begin{abstract}
Background: Vaccine hesitancy remains a public health issue, given the influence of parental belief, thoughts, feelings and perception on childhood vaccination. We assessed the process and impact of education intervention public health professionals conducted to eliminate the risks due to parental childhood vaccine indecisions behaviors.

Methods: We used cross-sectional research method with behavioral theories-informed tool to assess the process and impact of efforts on parental childhood vaccination hesitancy in our sample. Chi square statistic and logistic regression model were used to characterize the sample and test the study related hypotheses respectively.

Results: The overall response rate for the survey was 80\% (359 of 450). Sixty-three percent of the participants were female, $62 \%$ were employed full time, and $77 \%$ were educated above secondary school level. Ninety-five percent of the 450 participants cast their votes of confidence for the safety and protectiveness of childhood vaccines. In the multivariable logistic regression analysis, study participants with positive response to TV as a good source of information were 4 times as likely to perceive childhood immunization risks judged against those with negative response, adjusted prevalence odds ratio $(A P O R)=$ 4.35, 95\% Confidence Intervals $(C I)=0.10-0.74$.

Conclusions: The source of information significantly influenced vaccine hesitancy in our sample. These data is suggestive of the need for public health education via mass media in reducing vaccine hesitancy.

Keywords: Childhood immunization, parental vaccine hesitancy; risk communications; behavior change; vaccine acceptance

\section{Introduction}

Parental concerns about childhood vaccines are the main cause of the drop in vaccination coverage against infectious diseases at infancy that inevitably leads to reduced herd immunity and large-scale outbreaks of serious diseases; some of which result in infant mortality and lifelong disability in others. Persistent anxieties about the safety and usefulness of vaccines among the population threatened vaccination programs [1-3]. For instance, parental apprehensions about the safety of polio vaccine in Nigeria led to a regional outbreak and severely set back a polio elimination program [4].

Investigators have advanced convincing proofs of the value of vaccines to avoid infant infectious diseases and ensure healthy children [5-10]. Risk communication makes a major impact on how well society is prepared to cope with risk and react to crises and disasters. Effective evidence-based childhood vaccination indecision risk-benefit communication fosters tolerance for conflicting viewpoints, provides the basis for their resolution, and creates trust in the institutional means for assessing and managing the risk and related concerns $[11,12]$.
\end{abstract}


The need for approaches and strategies to address the ever increasing problems of vaccine hesitancy in countries and communities all over the world is urgent [13]. Public health professionals have educated parents to prevent the occurrence or persistence of the age long risks due to parental childhood vaccine hesitancy. However there are no data to indicate whether or not such media campaign is beneficial in terms of parental knowledge, skills and behavior modification in vaccine adherence. The current study assessed the process and impact of messages on the dimensions of the participants' decision-making behaviors to vaccinate their children or not against the backdrop of increasing vaccine hesitancy.

\section{Materials and methods}

We administered a semi-structured, anonymous, self-reported, pencil and paper, questionnaire in a crosssectional study to a cluster sampled 450 adult participants that met the inclusion criteria in Osun state in the southwestern part of Nigeria. We used the constructs of subjective risk perception and decision-making theories, such as Health Belief Model, Theory of Planned Behaviors, Protection Motivation Theory; hazard's severity, likelihood of occurring, and the effectiveness of preventive actions to build the tool in order to address the objective of this study [14 - 16]. We were cautious to avoid re-sampling or multiple sampling of the same individual. We obtained informed consent from each of the subjects that participated before collection of information using the questionnaire.

Inclusion Criteria: Potential participants were required to:

- $\quad$ Be residents of Osun State of Nigeria for more than six months incessantly prior to the study

- $\quad$ Understand, read, and speak English

- $\quad$ Be male or female not less than 18 years of age

- $\quad$ Comprehend and provide voluntary informed consent

Exclusion criteria: Participation was restricted from individuals who were:

- $\quad$ Mentally incapable of providing response

- $\quad$ Previously sampled by the same questionnaire

- $\quad$ Outside the scope of the inclusion criteria

Statistical Analyses: The data analyses in the study were in three stages: (a) tabulation of the response to each relevant variable, (b) test of association, (c) univariable and multivariable logistic regression. The $\mathrm{X}^{2}$ statistic with Fisher's exact test (correcting for small cell counts) was used to assess differences in the relevant variables. Using an unconditional, univariable logistic regression model, we examined separately the relationships between parental vaccine hesitancy risk perception and the relevant variables: media of communication on childhood immunization. Next, we performed multivariable analysis by using unconditional logistic regression model to control simultaneously for the possible confounding effects of these variables on childhood vaccine hesitance risk perception. All statistical tests were two tailed, at $\mathrm{p}<$ 0.05 significance level as type I error tolerance. We performed all analyses using STATA statistical software, version 13.0 (STATA Corp, College Station, TX).

\section{Results}

Table 1 presents the socio-demographic distribution/characteristics of the participants. The overall response rate for the survey was $80 \%$ (359 of 450). Among the respondents, 95\% reported that they were high school and above graduates, $89 \%$ were Yoruba speaking, $71 \%$ were legally marred, $63 \%$ were female and $54 \%$ were gainfully employed.

Tables $2 \mathrm{a}-2 \mathrm{c}$ show parental childhood vaccine-related beliefs, attitudes, behavioral intentions, behaviors, concerns, and information sources of infant vaccination. All respondents had at least some knowledge of childhood immunization. Eighty-seven percent believed that the vaccines would improve/help the conditions (87\%). Ninety-five percent of the participants cast their votes of confidence for the safety and protectiveness of childhood vaccine. The most common source of information on childhood vaccination was the radio $(76 \%)$. 
Table $2 \mathrm{~d}$ summarizes the parental childhood vaccine-related beliefs, attitudes, behavioral intentions, behaviors, concerns. The participants listed "Too many shots in one doctor's visit" as their least concern (52\%) followed by "Concerned about the child's pain from the shots" (53\%). Highly significant were the proportions of the participants that responded positively to the items, "Vaccines are effective against childhood VPDs" (96\%), "Confident childhood vaccines are protective and safe" (95\%), "I will vaccinate each of my children against VPDs as at when due" (95\%), "I am determined to be faithful to vaccinate my child against VPDs as at when due" (96\%), "I will encourage my neighbors to vaccinate children against VPDs as at when due" (96\%), and "I will encourage any pregnant teenager to vaccinate child against VPDs when due" (97\%).

Table 3 presents Parents' Sources of Information about Childhood Vaccination. The most important sources of information on childhood vaccines were the radio (76.3\%) and TV (74.1\%).

Table 4 illustrates the univariable logistic regression model. Participants with positive response to "There is enough prompt to vaccine-preventable diseases information action on": (a) the radio were 29\% more likely to perceive childhood immunization risk than those with negative response, $\mathrm{POR}=1.29, \mathrm{CI}=0.65$ -2.58 ; (b) TV were 2 times as likely as those with negative response, $\mathrm{POR}=2.63, \mathrm{CI}=1.53-4.51$; (c) The news media were 2 times as likely as those with negative response, $\mathrm{POR}=2.24, \mathrm{CI}=1.38-3.62$; (d) The Internet were 2 times as likely as those with negative response, $\mathrm{POR}=2.60, \mathrm{CI}=1.63-4.17$; and (e) Social media were about 3 times as likely as those with negative response, $\mathrm{POR}=2.96, \mathrm{CI}=1.85-4.73$.

Table 5 presents the multivariable logistic regression analysis. It showed that study participants with positive response for TV were 4 times as likely as those with negative response to perceive childhood immunization risks, APOR $=4.35, \mathrm{CI}=0.10-0.74$. Study participants with positive response for Social media were 3 times as likely as those with negative response to perceive childhood immunization risks, $\mathrm{APOR}=3.20, \mathrm{CI}=1.54-6.68$. Study participants with positive response for receiving information on the radio were $73 \%$ less likely to perceive childhood immunization risks compared with those that gave negative response $\mathrm{APOR}=0.27, \mathrm{CI}=0.10-0.74$.

\section{Discussion}

One major goal for public health has been to find better ways of informing the public about the evidence surrounding vaccination $[17,18]$. In this study, we assessed the potential predisposing factors to vaccine hesitancy, by characterizing our sample and testing some relevant hypotheses on potential predisposing factors to vaccine hesitancy.

There are a few relevant findings in our data. First, the result of this study showed that parents had the ability to accurately assess childhood vaccine hesitancy risks based on the probability of an incident and the possible consequences of the incidence. Secondly, parents reported positive attitudes about childhood vaccines. Most of them indicated confidence in childhood vaccine safety and felt that vaccines were important to the health of their children. This finding corroborated with previous data in other samples but similar setting [19-21].

Further, the findings in this study highlighted the process used to address parents' vaccines-specific concerns and questions, even among parents with high overall vaccines confidence plus the impact of the efforts. Given the strong role that the media and social media play in influencing people's perspectives on vaccination, a point of emphasis was related to the way in which public health agencies communicated the risks and benefits of vaccination. Communication needs to carefully and transparently convey risks as well as benefits, and that health agencies should seek to establish roles as 'honest brokers' who seek to neutrally and objectively communicate facts; thus exclude grounds for distrust.

Our data suggested the need for health professionals to provide more balanced information to parents and discuss with them that immunization was the right choice. The work established the importance of viewing parental childhood vaccination decision-making as a continuum, through which people were largely ambivalent about their personal choices to vaccinate or not. The concerns parents had about 
immunizations likely propelled some of their interactions with people they seek out and listen to and their information-seeking behaviors, which is a social phenomenon.

In today's digital age, many participants unequivocally identified the internet and social media as having great influence on public vaccines opinion. Developing means for campaigning and monitoring vaccine confidence via social and mass media, as well as better understanding the role of influential websites become increasingly important for assessing the dynamics of vaccine hesitancy.

Our findings have little precedent. However, our data are consistent with the results of a few previous researches on parental vaccine attitudes [22]. Freed et al [22] found that confidence in the necessity of vaccines to protect children's health was high among parents of young children and adolescents, yet concerns about issues such as potential adverse effects were common. Past research reports have suggested the need for communication approaches that recognized individual information needs $([22,23]$.

Increasing immunization rates is a public health priority because adequate immunization protects children against a number of infectious diseases that once were common. Immunizations improve quality of life, increase productivity, and prevent illness and death. Vaccines are cost-effective in preventing diseases.

\section{Strengths and limitations}

This current study has some strengths and limitations. Regarding it strengths: (a) the use of accurate point prevalence estimate (prevalence odds ratio, POR) in a cross-sectional survey research method to examine the association between the independent and dependent variables. POR does not inflate the effect size compared with odds ratio [24, 25], and (b) the ability to identify parental perception of childhood immunization risk determinants/factors in the sample, which have neither been studied nor documented as far as we knew, implying the sufficient sample size $(n=450)$ and the statistical power $(1-\beta=0.8,80 \%) \ldots$

Despite the strengths of this study there are some limitations. First, because the attitudes and concerns were self-reported, they were subject to social-desirability bias. The respondents may feel compelled to give a socially expected and acceptable answers and incomplete responses, considering perceived socioeconomic position when discussing their children's health rather than report their actual attitudes or behaviors.

Secondly, this study has restricted generalizability due to the variation in participants' experiences, as well as the education level of the sample. The study was limited to Nigerians in the southwestern state of Osun, a heterogeneous population. In effect the inference on the nonrandom sample is representative of those who completed the survey and not Nigerians as a whole. As a cross-sectional study, this work is short of temporal sequence and incapable of establishing causal association [26, 27].

Thirdly, the findings may be subject to potential selection bias as women and men who refused to participate in the survey may have differed from respondents. The accuracy of the study depended on the authenticity of the responses given by the participants.

Finally, like most non-experimental studies, unmeasured confounding may influence the findings, as well as residual confounding which may arise from design and multivariable or stratification analysis, since no matter how sophisticated a statistical package used to control for confounding, residual confounding remains [28]. However, it is highly unlikely that our findings are driven sole by unmeasured and residual confounding.

\section{Conclusion}

In summary, health messages about the risks of opting out of childhood vaccination programs which public health professionals communicated via TV to parents resonated and yielded remarkable impacts on infant vaccination hesitancy risks. In this sample, parents generally perceived the messages as believable and relevant to healthier children. 
Table 1. Study Characteristics

\begin{tabular}{|c|c|c|c|c|c|}
\hline Variable & Number & Percentage & Variables & Number & Percentage \\
\hline Tribe & & & Marital Status & & \\
\hline Yoruba & 320 & 89.0 & $\begin{array}{l}\text { Single/Never } \\
\text { Married }\end{array}$ & 81 & 22.5 \\
\hline Hausa & 1 & 0.3 & Legally Married & 254 & 70.7 \\
\hline Igbo & 15 & 4.3 & Cohabiting & 3 & 0.8 \\
\hline No Response & 23 & 6.4 & Separated & 1 & 0.3 \\
\hline Total & 359 & 100 & Divorced & 8 & 2.2 \\
\hline Age (Years) & & & Widowed & 2 & 0.6 \\
\hline$<21$ & 13 & 3.6 & No Response & 10 & 2.8 \\
\hline $21-25$ & 24 & 6.7 & $\begin{array}{l}\text { So' of Incom: } 30 \\
\text { days }\end{array}$ & & \\
\hline $26-30$ & 34 & 9.5 & A job & 194 & 54.0 \\
\hline $31-35$ & 46 & 12.8 & $\begin{array}{l}\text { Spouse/sex } \\
\text { partner(s) }\end{array}$ & 18 & 5.0 \\
\hline$>35$ & 183 & 51.0 & $\begin{array}{l}\text { Other family } \\
\text { members }\end{array}$ & 29 & 8.1 \\
\hline No Response & 59 & 16.4 & Friends & 15 & 4.2 \\
\hline Total & 359 & 100 & Trade sex for money & 8 & 2.2 \\
\hline $\begin{array}{l}\text { Education Level } \\
\text { Attained }\end{array}$ & & & Other illegal sources & 0 & 0 \\
\hline $\begin{array}{l}\text { No Formal } \\
\text { Education }\end{array}$ & 2 & 0.6 & No Income & 57 & 15.9 \\
\hline Primary & 4 & 1.1 & No Response & 38 & 10.6 \\
\hline $\begin{array}{l}\text { Some Secondary } \\
\text { School }\end{array}$ & 12 & 3.3 & Total & 359 & 100 \\
\hline $\begin{array}{l}\text { Secondary School } \\
\text { Graduate }\end{array}$ & 33 & 9.3 & $\begin{array}{l}\text { Income Last } 30 \\
\text { days }\end{array}$ & & \\
\hline $\begin{array}{l}\text { Some Post Sec } \\
\text { Sch (Uni, NDs) }\end{array}$ & 110 & 30.6 & No Income & 62 & 17.3 \\
\hline $\begin{array}{l}\text { Post Sec Sch Gra } \\
\text { (Univ, NDs) }\end{array}$ & 148 & 41.2 & $<\mathrm{N} 30,000$ & 83 & 23.1 \\
\hline $\begin{array}{l}\text { Postgraduate } \\
\text { (Masters, } \mathrm{PhD} \text { ) }\end{array}$ & 19 & 5.3 & $\mathrm{~N} 30,000-\mathrm{N} 50,000$ & 63 & 17.5 \\
\hline No Response & 31 & 8.6 & $>\mathrm{N} 50,000$ & 109 & 30.7 \\
\hline Total & 359 & 100 & No Response & 42 & 11.7 \\
\hline CV Knowledge & & & Total & 359 & 100 \\
\hline A lot & 297 & 82.7 & State of Origin & & \\
\hline Some & 62 & 17.3 & Osun & 249 & 69.4 \\
\hline None at all & 0 & 0 & Oyo & 12 & 3.3 \\
\hline Total & 359 & 100 & Ondo & 5 & 1.4 \\
\hline $\begin{array}{l}\text { Religious } \\
\text { Affiliation }\end{array}$ & & & Kwara & 5 & 1.4 \\
\hline Christianity & 248 & 69.1 & Ogun & 5 & 1.4 \\
\hline Muslim & 68 & 19.4 & Ekiti & 3 & 0.8 \\
\hline Other & 1 & 0.3 & Delta & 13 & 3.6 \\
\hline None & 4 & 1.2 & Imo & 11 & 3.1 \\
\hline Total & 359 & 100 & Rivers & 22 & 6.1 \\
\hline
\end{tabular}


Texila International Journal of Public Health

Volume 5, Issue 3, Sep 2017

\begin{tabular}{llllll}
$\begin{array}{l}\text { Work Situatn last } \\
\text { 30 days }\end{array}$ & & & No Response & 34 & 9.5 \\
Unemployed & 32 & 8.9 & Total & 359 & 100 \\
Full time work & 221 & 61.6 & Gender & & \\
Part time work & 27 & 7.5 & Male & 110 & 30.6 \\
Occasional work & 23 & 6.4 & Female & 223 & 63.5 \\
Retired & 1 & 0.3 & No Response & 21 & 5.9 \\
Disabled & 1 & 2.3 & Total & $\mathbf{3 5 9}$ & $\mathbf{1 0 0}$ \\
Home maker & 4 & 1.1 & & & \\
Student & 20 & 5.6 & & & \\
No Response & 30 & 8.4 & & & \\
Total & 359 & 100 & & & \\
\hline
\end{tabular}

Notes and abbreviations: $\mathrm{Sec}=$ Secondary, $\mathrm{Sch}=$ School, Gra $=$ Graduate, Uni $=$ University, NDs $=$ National Diplomas, $\mathrm{PhD}=$ Doctor of Philosophy, Situatn $=$ Situation, So' of Incom: 30 days $=$ Source of income last 30 days

Tables 2a. Parents' childhood vaccine-related, beliefs, attitudes, behavioral intentions, behaviors, concerns

\begin{tabular}{|c|c|c|c|c|c|}
\hline Covariates & Number & $\%$ & Covariates & Number & $\%$ \\
\hline $\begin{array}{l}\text { Vaccination is a highly } \\
\text { effective method of } \\
\text { preventing certain } \\
\text { infectious diseases }\end{array}$ & & & $\begin{array}{l}\text { Vaccines are generally very } \\
\text { safe }\end{array}$ & & \\
\hline Strongly Agree & 246 & 68.5 & Strongly Agree & 237 & 66.0 \\
\hline Agree & 99 & 27.6 & Agree & 101 & 28.1 \\
\hline I Don't Know & 4 & 1.1 & I Don't Know & 9 & 2.5 \\
\hline Disagree & 2 & 0.6 & Disagree & 8 & 2.2 \\
\hline Strongly Disagree & 0 & 0 & Strongly Disagree & 1 & 0.3 \\
\hline No Response & 8 & 2.2 & No Response & 3 & 0.8 \\
\hline Total & 100 & 100 & Total & 359 & 100 \\
\hline $\begin{array}{l}\text { Childhood immunization } \\
\text { is a cost-effective } \\
\text { approach to public health }\end{array}$ & & & $\begin{array}{l}\text { Routine immunization } \\
\text { programs protect most of the } \\
\text { world's children from a } \\
\text { number of infectious diseases } \\
\text { that previously claimed } \\
\text { millions of lives each year }\end{array}$ & & \\
\hline Strongly Agree & 222 & 61.8 & Strongly Agree & 267 & 74.4 \\
\hline Agree & 72 & 20.1 & Agree & 73 & 20.3 \\
\hline I Don't Know & 23 & 6.4 & I Don't Know & 5 & 1.4 \\
\hline Disagree & 15 & 4.2 & Disagree & 4 & 1.1 \\
\hline Strongly Disagree & 20 & 5.6 & Strongly Disagree & 2 & 0.6 \\
\hline No Response & 7 & 1.9 & No Response & 8 & 2.2 \\
\hline Total & 359 & 100 & Total & 359 & 100 \\
\hline $\begin{array}{l}\text { There is a lot of benefit } \\
\text { from vaccinating a child } \\
\text { against vaccine- } \\
\text { preventable diseases }\end{array}$ & & & $\begin{array}{l}\text { How likely are you to vaccinate } \\
\text { your child as at when due? }\end{array}$ & & \\
\hline Strongly Agree & 251 & 69.9 & Extremely Un Likely & 25 & 7.0 \\
\hline Agree & 77 & 21.5 & Unlikely & 5 & 1.4 \\
\hline I Don't Know & 14 & 3.9 & I Don't Know & 24 & 6.7 \\
\hline Disagree & 1 & 0.3 & Likely & 13 & 3.6 \\
\hline
\end{tabular}




\begin{tabular}{|c|c|c|c|c|c|}
\hline Strongly Disagree & 2 & 0.6 & Extremely Likely & 243 & 67.7 \\
\hline No Response & 14 & 3.9 & No Response & 49 & 13.6 \\
\hline Total & 359 & 100 & Total & 359 & 100 \\
\hline $\begin{array}{l}\text { How likely will you } \\
\text { vaccinate each of your } \\
\text { children against } \\
\text { vaccine-preventable } \\
\text { diseases when you have } \\
\text { them }\end{array}$ & & & $\begin{array}{l}\text { How determined are you to be } \\
\text { faithful to vaccinate your child } \\
\text { against vaccine-preventable } \\
\text { diseases as at when due? }\end{array}$ & & \\
\hline Very Likely & 174 & 48.5 & Very Determined & 293 & 81.6 \\
\hline Likely & 47 & 13.1 & Determined & 51 & 14.2 \\
\hline I Don't Know & 61 & 17.0 & I Don’t Know & 4 & 1.1 \\
\hline Unlikely & 3 & 0.8 & Not Determined & 0 & 0.0 \\
\hline Very Unlikely & 8 & 2.2 & Not Very Determined & 1 & 0.3 \\
\hline No Response & 66 & 18.4 & No Response & 10 & 2.8 \\
\hline Total & 359 & 100 & Total & 359 & 100 \\
\hline
\end{tabular}

Tables 2b. Parents' childhood vaccine-related, beliefs, attitudes, behavioral intentions, behaviors, concerns continues

\begin{tabular}{|c|c|c|c|c|c|}
\hline Covariates & Number & $\%$ & Covariates & Number & $\%$ \\
\hline $\begin{array}{l}\text { How important is it to } \\
\text { vaccinate the child as at } \\
\text { when due? }\end{array}$ & & & $\begin{array}{l}\text { ReLeader can influence } \\
\text { my decision to vaccinate } \\
\text { child }\end{array}$ & & \\
\hline Not Very Important & 23 & 6.4 & Strongly Agree & 105 & 29.2 \\
\hline Not Important & 7 & 1.9 & Agree & 159 & 44.3 \\
\hline I Don't Know & 7 & 1.9 & I Don't Know & 29 & 8.1 \\
\hline Important & 35 & 9.8 & Disagree & 28 & 7.8 \\
\hline Very Important & 268 & 74.7 & Strongly Disagree & 4 & 1.1 \\
\hline No Response & 19 & 5.3 & No Response & 34 & 9.5 \\
\hline Total & 359 & 100 & Total & 359 & 100 \\
\hline $\begin{array}{l}\text { Parents can influence my } \\
\text { decision to vaccinate child }\end{array}$ & & & $\begin{array}{l}\text { PHP can influence my } \\
\text { decision to vaccinate child }\end{array}$ & & \\
\hline Strongly Agree & 185 & 51.5 & Strongly Agree & 180 & 50.1 \\
\hline Agree & 127 & 35.4 & Agree & 110 & 30.6 \\
\hline I Don't Know & 13 & 3.6 & I Don’t Know & 14 & 3.9 \\
\hline Disagree & 3 & 0.8 & Disagree & 16 & 4.5 \\
\hline Strongly Disagree & 1 & 0.3 & Strongly Disagree & 2 & 0.6 \\
\hline No Response & 30 & 8.4 & No Response & 37 & 10.3 \\
\hline Total & 359 & 100 & Total & 359 & 100 \\
\hline $\begin{array}{l}\text { PCP can influence my } \\
\text { decision to vaccinate child }\end{array}$ & & & $\begin{array}{l}\text { Not vaccinating a child } \\
\text { against vaccine- } \\
\text { preventable diseases is life } \\
\text { threatening for the child }\end{array}$ & & \\
\hline Strongly Agree & 179 & 49.9 & Strongly Agree & 215 & 59.9 \\
\hline Agree & 106 & 29.5 & Agree & 92 & 25.6 \\
\hline I Don't Know & 7 & 1.9 & I Don’t Know & 13 & 3.6 \\
\hline Disagree & 31 & 8.6 & Disagree & 25 & 7.0 \\
\hline Strongly Disagree & 1 & 0.3 & Strongly Disagree & 4 & 1.1 \\
\hline No Response & 35 & 9.8 & No Response & 10 & 2.8 \\
\hline
\end{tabular}


Texila International Journal of Public Health

Volume 5, Issue 3, Sep 2017

\begin{tabular}{|c|c|c|c|c|c|}
\hline $\begin{array}{l}\text { Total } \\
\text { An unvaccinated child } \\
\text { against VPDs diseases is } \\
\text { susceptible to those } \\
\text { diseases at any time }\end{array}$ & 359 & 100 & $\begin{array}{l}\text { Total } \\
\text { There is a lot of benefit } \\
\text { from vaccinating a child } \\
\text { against vaccine- } \\
\text { preventable diseases }\end{array}$ & 359 & 100 \\
\hline Strongly Agree & 204 & 56.8 & Strongly Agree & 251 & 69.9 \\
\hline Agree & 116 & 32.3 & Agree & 77 & 21.5 \\
\hline I Don’t Know & 18 & 5.0 & I Don’t Know & 14 & 3.9 \\
\hline Disagree & 6 & 1.7 & Disagree & 1 & 0.3 \\
\hline Strongly Disagree & 2 & 0.6 & Strongly Disagree & 2 & 0.6 \\
\hline No Response & 13 & 3.6 & No Response & 14 & 3.9 \\
\hline Total & 359 & 100 & Total & 359 & 100 \\
\hline $\begin{array}{l}\text { Not vaccinating a child } \\
\text { against vaccine- } \\
\text { preventable diseases can } \\
\text { result in disability for life }\end{array}$ & & & $\begin{array}{l}\text { The consequences of not } \\
\text { vaccinating a child } \\
\text { against VPDs are severe }\end{array}$ & & \\
\hline Strongly Agree & 285 & 79.4 & Strongly Agree & 182 & 50.7 \\
\hline Agree & 44 & 12.3 & Agree & 108 & 30.1 \\
\hline I Don't Know & 11 & 3.1 & I Don't Know & 35 & 9.8 \\
\hline Disagree & 2 & 0.6 & Disagree & 17 & 4.7 \\
\hline Strongly Disagree & 0 & 0.0 & Strongly Disagree & 12 & 3.3 \\
\hline No Response & 17 & 4.7 & No Response & 5 & 1.4 \\
\hline Total & 359 & 100 & Total & 359 & 100 \\
\hline
\end{tabular}

Notes and abbreviations: ReLeader $=$ Religious Leader, PCP $=$ Primary Care Physician, PHP $=$ Public Health Practitioner, VPDs = Vaccine-preventable diseases

Tables 2c. Parents' childhood vaccine-related, beliefs, attitudes, behavioral intentions, behaviors, concerns continues

\begin{tabular}{|c|c|c|c|c|c|}
\hline Covariates & Number & $\%$ & Covariates & Number & $\%$ \\
\hline $\begin{array}{l}\text { The health of a family } \\
\text { is the family's wealth }\end{array}$ & & & $\begin{array}{l}\text { Childhood vaccination } \\
\text { is essential for the } \\
\text { child's health thru 'out } \\
\text { life }\end{array}$ & & \\
\hline True & 349 & 97.2 & True & 335 & 93.3 \\
\hline False & 4 & 1.1 & False & 15 & 4.2 \\
\hline No Response & 6 & 1.7 & No Response & 9 & 2.5 \\
\hline Total & 359 & 100 & Total & 359 & 100 \\
\hline $\begin{array}{l}\text { I intend to ensure all } \\
\text { my children are } \\
\text { vaccinated }\end{array}$ & & & $\begin{array}{l}\text { I will vaccinate each of } \\
\text { my children against } \\
\text { vaccine-preventable } \\
\text { diseases as at when } \\
\text { due }\end{array}$ & & \\
\hline Yes & 322 & 89.7 & Yes & 342 & 95.3 \\
\hline No & 15 & 4.2 & No & 9 & 2.5 \\
\hline No Response & 22 & 6.1 & No Response & 8 & 2.2 \\
\hline $\begin{array}{l}\text { Total } \\
\text { I will encourage my } \\
\text { neighbors to vaccinate }\end{array}$ & 359 & 100 & $\begin{array}{l}\text { Total } \\
\text { All my children } \\
\text { received all the }\end{array}$ & 359 & 100 \\
\hline
\end{tabular}


vaccine-preventable

diseases as at when

due

Yes

No

No Response

Total

My child's wellbeing is important to me

Yes

No

No Response

Total

The injection is painful for a child

Yes

No

No Response

Total

The disease conditions are dreadful/terrible

Yes

No

No Response

Total

The diseases are real (exist)

Yes
No
No Response
Total

340

3

16

359

346

8

5

359

192

158

9

359

290

63

6

359

296

52

11

359
96.4

2.2

1.4

100 childhood vaccines appropriately

$$
\text { Yes }
$$

309

11

No

Not Applicable

No Response

Total

I will encourage any

pregnant teenager to

ensure they vaccinate

their children against

vaccine-preventable

diseases when due

$94.7 \quad$ Yes

$0.8 \quad$ No

4.5

100

No Response

Total

The vaccines will

improve/help the conditions

53.5 Yes

44.0

2.5

100

No

No Response

Total

The vaccines are too many

$80.8 \quad$ Yes

17.5 No

1.7

100

No Response

Total

7

359

The diseases are a

hoax (deception,

fraud, trick)

82.4 Yes

No

3.1

No

100 Total
86.1

3.1

6.1

4.7

100
188

52.4

164

106

243

$349 \quad 97.2$

$5 \quad 1.4$

$5 \quad 1.4$

$359 \quad 100$

$312 \quad 86.9$

$32 \quad 8.9$

$15 \quad 4.2$

$359 \quad 100$

$359-100$

Table 2d. Summary of parents' childhood vaccine-related, beliefs, attitudes, behavioral intentions, behaviors, concerns. When asked specific questions to measure the beliefs, attitudes, and behaviors the affirmative responses were

\begin{tabular}{ll}
\hline Covariate & Percentage \\
\hline The health of the family was the wealth of the family & $\mathbf{9 7}$ \\
Vaccines are effective against childhood vaccine-preventable diseases & $\mathbf{9 6}$ \\
Confident childhood vaccines are protective and safe & $\mathbf{9 5}$ \\
Concerned about the child's pain from the shots & $\mathbf{5 3}$ \\
Too many shots in one doctor's visit & $\mathbf{5 2}$ \\
The disease conditions are dreadful/terrible & $\mathbf{8 1}$
\end{tabular}


Texila International Journal of Public Health

Volume 5, Issue 3, Sep 2017

I will encourage any pregnant teenager to vaccinate child against VPDs

when due

I will encourage my neighbors to vaccinate children against VPDs as at $\quad \mathbf{9 6}$

when due

I will vaccinate each of my children against VPDs as at when due

95

The health of a family is the family's wealth (Benefits of childhood

97

vaccine)

Childhood vaccination is essential for the child's health throughout life 93

I am determined to be faithful to vaccinate my child against VPDs as at 96

when due

The consequences of not vaccinating a child against VPDs are severe $\quad \mathbf{8 1}$

There is a lot of benefit from vaccinating a child against VPDs 91

Not vaccinating a child against VPDs can result in disability for life $\quad 91$

Refusal to vaccinate children against VPDs is a health risk for the children $\quad \mathbf{8 7}$

for life

$\begin{array}{ll}\text { The vaccines will improve/help the conditions } & \mathbf{8 7}\end{array}$

Childhood immunization is a cost-effective approach to public health $\quad \mathbf{8 2}$

Table 3. Parents' Sources of Information about Childhood Vaccination

\begin{tabular}{llllll}
\hline Covariates & No & $\%$ & Covariates & No & $\%$ \\
\hline Television & & & Radio & & \\
Yes & 266 & 74.1 & Yes & 274 & 76.3 \\
No & 93 & 25.9 & No & 85 & 23.7 \\
Total & 359 & 100.0 & Total & 359 & 100.0 \\
Newspaper & & & Magazines & & \\
Yes & 177 & 49.3 & Yes & 152 & 42.3 \\
No & 182 & 50.7 & No & 207 & 57.7 \\
Total & 359 & 100.0 & Total & 359 & 100.0 \\
A relative or friend & & & Workplace & & \\
Yes & 216 & 60.2 & Yes & 211 & 58.8 \\
No & 143 & 39.8 & No & 148 & 41.2 \\
Total & 359 & 100.0 & Total & 359 & 100.0 \\
Schools & & & Clinic & & \\
Yes & 184 & 51.3 & Yes & 240 & 66.8 \\
No & 175 & 48.7 & No & 119 & 33.2 \\
Total & 359 & 100.0 & Total & 359 & 100.0 \\
Billboard & & & *Other Sources & & \\
Yes & 117 & 32.6 & Yes & 83 & 23.1 \\
No & 242 & 67.4 & No & 276 & 76.9 \\
Total & 359 & 100.0 & Total & 359 & 100.0 \\
\hline
\end{tabular}

*Other Sources mentioned included

1. Seminars/Workshops

2. Market places

3. Town Announcers/Criers

4. Internet

5. Worship Centers (Church/Mosques). 
Table 4. Univariable Logistic Regression Analysis of the Medium of Communication of Childhood Immunization

\begin{tabular}{|c|c|c|}
\hline $\begin{array}{l}\text { Potential Predictors of Childhood Immunization } \\
\text { Risk Perception }\end{array}$ & $\begin{array}{l}\text { Prevalence } \\
\text { Odds Ratio } \\
\text { (POR) }\end{array}$ & $\begin{array}{l}95 \% \\
\text { Confidence } \\
\text { Interval (CI) }\end{array}$ \\
\hline \multicolumn{3}{|l|}{$\begin{array}{l}\text { There is enough prompt to VPDs information action on } \\
\text { the radio in Nigeria }\end{array}$} \\
\hline No & 1.0 (reference) & ref \\
\hline Yes & 1.29 & $0.65-2.58$ \\
\hline \multicolumn{3}{|l|}{$\begin{array}{l}\text { There is enough prompt to VPDs information action on } \\
\text { TV in Nigeria }\end{array}$} \\
\hline No & 1.0 (reference) & ref \\
\hline Yes & 2.63 & $1.53-4.51$ \\
\hline \multicolumn{3}{|l|}{$\begin{array}{l}\text { There is enough prompt to VPDs information action on } \\
\text { the news media in Nigeria }\end{array}$} \\
\hline No & 1.0 (reference) & ref \\
\hline Yes & 2.24 & $1.38-3.62$ \\
\hline \multicolumn{3}{|l|}{$\begin{array}{l}\text { There is enough prompt to VPDs information action on } \\
\text { the Internet }\end{array}$} \\
\hline No & 1.0 (reference) & ref \\
\hline Yes & 2.60 & $1.63-4.17$ \\
\hline \multicolumn{3}{|l|}{$\begin{array}{l}\text { There is enough prompt to VPDs information action on } \\
\text { Social media }\end{array}$} \\
\hline No & 1.0 (reference) & ref \\
\hline Yes & 2.96 & $1.85-4.73$ \\
\hline
\end{tabular}

Notes and abbreviations: VPDs $=$ Vaccine-preventable diseases

Table 5. Multivariable Logistic Regression model of the Medium of Communication of Childhood Immunization

\begin{tabular}{|c|c|c|c|c|}
\hline $\begin{array}{l}\text { Potential Predictors of Childhood } \\
\text { Immunization Risk Perception }\end{array}$ & $\begin{array}{l}\text { Adjusted } \\
\text { Prevalence } \\
\text { Odds } \\
\text { Ratio } \\
\text { (APOR) } \\
\end{array}$ & $\begin{array}{l}95 \% \\
\text { Confidence } \\
\text { Interval (CI) }\end{array}$ & $\begin{array}{l}\text { Wald } \\
\text { test } \\
(Z)\end{array}$ & $\begin{array}{l}\text { p-value } \\
|\mathrm{Z}| \\
(\alpha<0.05 \\
)^{2}\end{array}$ \\
\hline $\begin{array}{l}\text { There is enough prompt to VPDs } \\
\text { information action on the radio in Nigeria }\end{array}$ & 0.27 & $0.10-0.74$ & -2.56 & 0.01 \\
\hline $\begin{array}{l}\text { There is enough prompt to VPDs } \\
\text { information action on TV in Nigeria }\end{array}$ & 4.35 & $1.56-12.13$ & 2.81 & 0.00 \\
\hline $\begin{array}{l}\text { There is enough prompt to VPDs } \\
\text { information action on the news media in } \\
\text { Nigeria }\end{array}$ & 0.57 & $0.22-1.48$ & -1.16 & 0.25 \\
\hline $\begin{array}{l}\text { There is enough prompt to VPDs } \\
\text { information action on the Internet }\end{array}$ & 1.12 & $0.48-2.60$ & 0.25 & 0.80 \\
\hline $\begin{array}{l}\text { There is enough prompt to VPDs } \\
\text { information action on Social media }\end{array}$ & 3.20 & $1.54-6.68$ & 3.10 & 0.00 \\
\hline
\end{tabular}

Notes and abbreviations: VPDs $=$ Vaccine-preventable diseases, $\mathrm{TV}=$ Television 
Texila International Journal of Public Health

Volume 5, Issue 3, Sep 2017

\section{References}

[1]. Bond L, and Nolan T. Making sense of perceptions of risk of diseases and vaccinations: a qualitative study combining models of health beliefs, decision-making and risk perception. BMC Public Health, 2011; 11:943.

[2]. Coggon D, Barker D, and Rose G. Epidemiology for the uninitiated (Chapter 8, "Case-control and cross-sectional studies"). ( $5^{\text {th }}$ Ed.), London: BMJ (British Medical Journal) Publishing; 2003.

[3]. Drehob PA, Roush SW, Stover BH, et al. Public Health Surveillance Workforce of the Future. CDC Scientific Education and Professional Development Program Office and National Center for Immunization and Respiratory Diseases, 2012;61(03):25 - 29

[4]. Dubé E, Vivion M, and MacDonald NE. Vaccine hesitancy, vaccine refusal and the anti-vaccine movement: influence, impact and implications. Expert Review of Vaccines, 2015; 14(1):99-117.

[5]. Dubé E, Gagnon D, Nickels E, et al. Mapping vaccine hesitancy - country-specific characteristics of a global phenomenon. Vaccine, 2014;32(49):6649-6654

[6]. Dubé E, Gagnon D, Zhou Z, et al. Parental Vaccine Hesitancy in Quebec (Canada). PLOS Currents Outbreaks, $20161^{\text {st }}$ Ed doi: 10.1371/currents.outbreaks.9e239605f4d320c6ad27ce2aea5aaad2

[7]. Dubé E, Laberge C, Guay M, et al. Vaccine hesitancy: An overview. Human Vaccine Immunotherapeutic, 2013; 9(8): $1763-1773$.

[8]. Frenk J, Chen L, Bhutta ZA, et al. Health professionals for a new century: transforming education to strengthen health systems in an interdependent world. Lancet, 2010; 376:1923 - 1958.

[9]. Freed GL, Clark SJ, Butchart AT, et al. Parental vaccine safety concerns in 2009. Pediatrics, 2010;125(4):654659

[10]. Gellin BG, Maibach EW, and Marcuse EK. Do parents understand immunizations: A national telephone survey. Pediatrics, 2000;106(5):1097-1102

[11]. Gust D, Brown C, Sheedy K, et al. Immunization attitudes and beliefs among parents (beyond a dichotomous perspective). American Journal of Health Behavior, 2005; 29:81 - 92.

[12]. Holmes L, (Jr), Chan W, Jiang Z, et al. Effectiveness of androgen deprivation therapy in prolonging survival of older men treated for locoregional prostate cancer. Prostate Cancer Prostatic Disease, 2007; 10(4):388 - 395.

[13]. Kapp C. Nigerian states again boycott polio-vaccination drive. Muslim officials have rejected assurances that the polio vaccine is safe-leaving Africa on the brink of re-infection. Lancet, 2004;363:709

[14]. Kestenbaum LA, and Feemster KA. Identifying and addressing vaccine hesitancy. Pediatrics Annals, 2015;44(4):e71-75

[15]. Leask J, Braunack-Mayer A, and Kerridge I. Consent and public engagement in an era of expanded childhood immunisation. Journal of Paediatri and Child Health, 2011;47:603-607

[16]. Larson HJ, Jarrett C, Eckersberger E, et al. Understanding vaccine hesitancy around vaccines and vaccination from a global perspective: a systematic review of published literature, 2007-2012. Vaccine, 2014; 32(19):2150-2159. [17]. MacDonald NE, Smith J, and Appleton M. Risk perception, risk management and safety assessment: what can governments do to increase public confidence in their vaccine system? Biologicals, 2012; 40:384 -388.

[18]. Neuwirth K, Dunwoody S, and Griffin RJ. Protection Motivation and Risk Communication. Risk Analysis, 2000; 20(5):721-734.

[19]. Poland GA, Jacobson RM, and Ovsyannikova IG. Trends affecting the future of vaccine development and delivery: the role of demographics, regulatory science, the anti-vaccine movement, and vaccinomics. Vaccine, 2009; 27:3240 - 3244 .

[20]. Peretti-Watel P, Larson HJ, Ward JK, et al. Vaccine hesitancy: clarifying a theoretical framework for an ambiguous notion. PLoS Currents, 2015; 7.

[21]. Prentice-Dunn S, and Rogers RW. Protection motivation theory and preventive health: Beyond the health belief model. Health Education Research, 1986; 1(3):153-161.

[22]. Poland GA, and Jacobson RM. The age-old struggle against the antivaccinationists. New England Journal of Medicine, 2011; 364(2):97 - 99.

[23]. Reynolds B, and Seeger MW. Crisis and Emergency Risk Communication as an Integrative Model. Journal of Health Communication, 2005;10:43-55 
[24]. Reynolds B, and Seeger MW. Crisis and Emergency Risk Communication. US Department of Health and Human Services, Centers for Disease control and Prevention. 2012. Available at https://emergency.cdc.gov/cerc/resources/pdf/cerc_2012edition.pdf Accessed November 16, 2016.

[25]. Siddiqui M, Salmon DA, and Omer SB. Epidemiology of vaccine hesitancy in the United States. Human Vaccine Immunotherapeutics, 2013; 9(12):2643 - 2648.

[26]. Salmon DA, Dudley MZ, Glanz JM, et al. Vaccine hesitancy: causes, consequences, and a call to action. American Journal of Preventive Medicine, 2015; 49(6 Suppl 4):S391-398.

[27]. Trochim WMK, and Donnelly JP. The research methods knowledge base. ( ${ }^{\text {rd }}$ Ed.), New York, NY: Atomic Dog; 2006.

[28]. Wilson RJ, Paterson P, Jarrett C, et al. Understanding factors influencing vaccination acceptance during pregnancy globally: A literature review. Vaccine, 2015;33(47):6420-6429 